\title{
Thermal treatment of dusts from non ferrous metallurgical industries $\left(^{(\cdot)}\right.$
}

\author{
Noureddine Menad", Ibrahim Gaballah**, Fernando García-Carcedo**, \\ Nilo Cornejo***, Ángel Hernández ${ }^{* * * *}$ and Serafín Ferreira***
}

\begin{abstract}
Three samples of dusts generated by the non ferrous metallurgical industries are treated between 200 and $800^{\circ} \mathrm{C}$ in controlled oxidizing and reducing atmospheres. The objective of this study is to recover the valuable metals from these wastes. The treatments of these solids under oxidizing conditions at $700{ }^{\circ} \mathrm{C}$ are well adapted for two samples. The totality of valuable elements are concentrated in the treatments' residues. The use of hydrogen at $600{ }^{\circ} \mathrm{C}$, permits the removal of up to $100 \%$ of valuable metals contained in the treated industrial wastes. The recovery rate of valuable metals $(\mathrm{Pb}, \mathrm{Zn}, \mathrm{Cu})$ as well as the Global Decontamination Factor are reported.
\end{abstract}

Keywords Metallurgical dusts. Oxidizing treatment. Reducing treatment. Valuable metals. Toxic elements.

\section{Tratamiento térmico de polvos procedentes de metales no férreos}

Resumen

Palabras clave

\begin{abstract}
Se han tratado tres muestras procedentes de la industria metalúrgica no férrea entre $200 \mathrm{y}$ $800{ }^{\circ} \mathrm{C}$, en atmósferas oxidantes o reductoras controladas. El objetivo de este estudio es recuperar cuanto sea posible de los elementos valiosos de estos residuos. Los tratamientos bajo condiciones oxidantes a $700^{\circ} \mathrm{C}$ han dado buenos resultados en dos muestras, en donde la totalidad de los elementos valiosos se concentraba en los residuos de tratamiento. El uso del hidrógeno a $600{ }^{\circ} \mathrm{C}$ permite la separación de hasta el $100 \%$ de los metales valiosos contenidos en los residuos industriales tratados. Finalmente, se detallan las tasas de recuperación de los metales plomo, zinc y cobre así como el factor de descontaminación global (GDF).
\end{abstract}

Polvos metalúrgicos. Atmósfera oxidante. Atmósfera reductora. Elementos metálicos valiosos. Elementos tóxicos.

\section{INTRODUCTION}

The metallurgical industries generate unavoidable wastes that can be very toxic. The evolution of the regulation on their waste disposal and the public opinion pressure push the scientific and technical communities to find a solution for this problem. Although the authorities and the public opinion oppose to open new sites, hundreds of legal or illegal storage sites were established during last decades. Currently, the high cost of waste disposal reduces the enterprises' competitiveness and decreases their market share on the global level. The wastes generated from industries should be treated either for recycling or for decreasing their toxicity and/or their volume, because, their amount does effect the atmosphere, soil and water resources $^{[1]}$.

The metallurgical dusts have variable compositions. These wastes have a fin grain size that increase their reactivity. They contain a non negligible amount of valuable metals.

This paper describes the effect of thermal treatment, under controlled atmosphere on dusts generated by the non-ferrous metallurgical sector. The treatment is performed at different temperatures and oxidizing and reducing atmospheres. The toxic elements' elimination and the valuable metals' concentration in the treated residues are determined. To correlate these two

(•) Trabajo recibido el día 20 de julio de 1999 y aceptado en su forma final el 13 de junio de 2000.

$\left(^{*}\right.$ Luleå University of Technology, Div. of Chemical and Metallurgical Engineering, Se-951 87, Luleå (Sweden).

(**) Mineral Processing and Environmental Engineering, LEM, Associated to CNRS URA 235, INPL, ENSG, B. P. 40, 54501 Vandœuvre (France).

$\left(^{* * *}\right)$ Centro Nacional de Investigaciones Metalúrgicas, CENIM (CSIC). Avda. Gregorio del Amo, 8. 28040 Madrid (España). 
aspects, the Global Decontamination Factor (GDF) is suggested to measure the efficiency of such treatments. Finally, the possibility of use the recycled residues, in the conventional industrial reactors, is considered.

\section{THERMODYNAMIC CONSIDERATIONS}

A full thermodynamic analysis of the eventual interactions of these solid wastes with the atmosphere of treatment is almost impossible because of unlimited possible interactions of compounds contained in these wastes with each other and with the gas mixture as the temperature increases. However, the evolution of the standard free energies of oxidation or reduction of major compounds pertinent to samples examined in this study can be of help for the determination of possible main reactions.

The oxidation of the majority of compounds contained in the three samples is thermodynamically possible. The most favourable reaction is the oxidation of galena to Anglesite as reported in ${ }^{[2]}$. The oxidation of $\mathrm{HgSe}$ is the least thermodynamically probable reaction. At $600{ }^{\circ} \mathrm{C}$, the thermodynamic feasibility for the oxidation of the major compounds may be classified, in decreasing order, as follows: $\mathrm{ZnS}>\mathrm{PbS}>\mathrm{Cu}_{2} \mathrm{Se}>$ $\mathrm{HgSe}$. The reduction of these residues will produce metallic elements or will lead to elements having lower oxidation states. The reduction of $\mathrm{HgSe}$ is favourable at $\mathrm{T}>627{ }^{\circ} \mathrm{C}$. However, all other reduction reactions are possible at temperatures higher than $477^{\circ} \mathrm{C}$.

\section{MATERIALS AND EXPERIMENTAL PROCEDURES}

\section{1. Materials}

The non ferrous metallurgy generates different wastes from the hydro and/or pyrometallurgical processes. These residues contain valuable metals such as copper, lead, zinc, etc., and toxic elements such as arsenic, mercury, cadmium, selenium, ... Three samples (A, B, C) obtained from different units of the same European operator are examined in this work. Their contents of toxic and valuable elements are 7 to $23 \%$ and 24 to $54 \%$, respectively (Table I). These samples are friable and contain about 1.4 to $52 \%$ of humidity. Their specific surface areas, are 1.4 to $8.5 \mathrm{~m}^{2} / \mathrm{g}$. Their particle size is small and their median size $\left(d_{50}\right)$ varies from 6 to $50 \mu \mathrm{m}$. The samples are dried at $105^{\circ} \mathrm{C}$ before their treatment. The raw dried samples are characterized by X-ray diffraction (XRD), scanning electron microscope (SEM) and chemical analysis (CA).

The XRD analysis of these samples indicates the presence of $\mathrm{As}_{2} \mathrm{O}_{3}, \mathrm{PbS}, \mathrm{PbSO}_{4}, \mathrm{Cu}_{2} \mathrm{Se}$, $\mathrm{Fe}_{2}\left(\mathrm{SO}_{4}\right)_{3}, \mathrm{HgSO}_{4}, \mathrm{~Pb}_{5}\left(\mathrm{AsO}_{4}\right)_{3} \mathrm{Cl}, \mathrm{ZnS}, \mathrm{SiO}_{2}{ }^{[3]}$. To determine the toxicity of these samples, a standard leaching test is performed according to the French procedure AFNOR ${ }^{*}$ X 31-210. The concentration of the elements in the lixiviate exceeded the limits of admission in disposals for hazardous wastes. Therefore, such wastes are considered dangerous for the environment and should be treated before their storage in waste disposal sites.

\subsection{Experimental procedures}

The thermogravimetric (TG) experiments were done in non isothermal conditions using a Cahn microbalance described previously ${ }^{[4}$ and 5]. One may mention that the waste samples were deposed in a quartz crucible connected to the weighting unit of the balance by quartz rods. The sample's weight was about $100 \mathrm{mg}$. The samples were heated directly in the chosen controlled atmosphere at a heating rate of about $10{ }^{\circ} \mathrm{C} / \mathrm{min}$. A data acquisition system was used to record the sample's weight and temperature as a function of time.

*AFNOR: Association Française de la NORmalisation.

Table I. Chemical analysis of dust samples generated from metallurgical processes (weight percentage)

Tabla I. Análisis químico de las muestras (\% en peso)

\begin{tabular}{lrrrrrrrrrrrrrr}
\hline $\mathrm{SN}^{\circ}$ & $\mathrm{Pb}$ & $\mathrm{Zn}$ & $\mathrm{Cu}$ & $\mathrm{Ag}$ & $\mathrm{As}$ & $\mathrm{Hg}$ & $\mathrm{Se}$ & $\mathrm{Cd}$ & $\mathrm{S}$ & $\mathrm{Ca}$ & $\mathrm{Fe}$ & $\mathrm{Sb}$ & $\mathrm{TE}$ & $\mathrm{VM}$ \\
\hline $\mathrm{A}$ & 33.2 & 0.2 & 8.2 & 0.18 & 0.6 & 3.2 & 3.3 & 0.1 & 11.5 & 0.0 & 0.0 & $\mathrm{ND}$ & 7.2 & 41.6 \\
$\mathrm{~B}$ & 4.8 & 16.9 & 2.1 & 0.03 & 21.7 & 0.6 & $\mathrm{ND}$ & 0.8 & 22.9 & 0.1 & 1.0 & 0.1 & 23.1 & 23.8 \\
$\mathrm{C}$ & 35.9 & 18.3 & 0.2 & 0.02 & 10.7 & 0.0 & $\mathrm{ND}$ & 0.3 & 2.1 & $\mathrm{ND}$ & $\mathrm{ND}$ & $\mathrm{ND}$ & 11.0 & 54.4 \\
\hline
\end{tabular}


The treatment under controlled atmosphere was performed between 200 and $800{ }^{\circ} \mathrm{C}$ using the apparatus described in reference ${ }^{[6]}$. A predefined flow rate was obtained using the adequate flow meter. Water vapor was eliminated by passing the gas through $\mathrm{P}_{2} \mathrm{O}_{5}$ column. The furnace was heated to the desired temperature along with the reacting gas flowing in the system. The experiment started by introducing about $10 \mathrm{~g}$ of the sample, in the central zone of the furnace. The investigated temperature range was 200 to $800^{\circ} \mathrm{C}$. The volatile compounds were condensed in the cold part of the reactor. The exhausted gases were purified before their release to the atmosphere. The treated residues and the condensates were examined by XRD and SEM analyses. Based on the results, the most decontaminated residues were subjected to classical chemical analysis.

\section{RESULTS AND DISCUSSION}

\subsection{Oxidizing treatment}

The dried raw samples were treated with air using the apparatus schematized in references ${ }^{[4}$ and 6$]$. The effect of the total gas flow rate on the reaction rate was studied at $700^{\circ} \mathrm{C}$. It was found that the reaction rate is almost independent of the gas velocity for a flow rate of about $40 \mathrm{~L} / \mathrm{h}$. The treatment of the three samples was performed using a flow rate equal to 40 $\mathrm{L} / \mathrm{h}$ and a reaction time of $4 \mathrm{~h}$.

The thermogravimetric analysis (TGA) of three samples shows the weight losses at about $200^{\circ} \mathrm{C}$. This is due to the dehydration of some compounds and to the partial or complete volatilisation of arsenic, mercury and selenium compounds. At about $400{ }^{\circ} \mathrm{C}$, the sample B decreases the weight. This could be explained by the full volatilisation of arsenic compounds of this sample that contain $22 \%$ As. At about $500^{\circ} \mathrm{C}$, the oxidation of metal sulfides and/or selenides is probably the cause of the weight loss at this temperature. Other reactions are possible and depend on the initial composition of the sample. The qualitative chemical analysis of the treatments' residues of these samples indicates that the majority of the toxic elements such as arsenic, mercury, selenium and cadmium are eliminated at temperatures $\leq 700^{\circ} \mathrm{C}$. To have sufficient amount of the treated residues for chemical analysis and examination by XRD, SEM, etc., isothermal treatments between 200 and $800^{\circ} \mathrm{C}$ were performed using an initial sample weight of about $10 \mathrm{~g}$.
One may underline that the experimental conditions of the isothermal treatment of these samples will favour the reactions' equilibrium than in the case of the TGA for the same solid in non isothermal conditions.

The qualitative chemical composition indicates that the compounds of arsenic, mercury and selenium were concentrated in the condensates. The treatment's residues of samples A and B were almost free of arsenic, mercury and selenium compounds. Valuable elements' compounds were concentrated in these residues.

The sample $\mathrm{C}$ contains mimetite $\mathrm{Pb}_{5}\left(\mathrm{AsO}_{4}\right)_{3} \mathrm{Cl}$. The thermal decomposition of this compound leads to a partial chlorination of the valuable elements. At $700{ }^{\circ} \mathrm{C}$, the produced chlorides were volatilized and recovered in the condensates up to $99 \%$ As; mercury and selenium were eliminated ${ }^{[7]}$. On may stress that several phases were amorphous and not identified by XRD. On the other hand, zinc chloride was not identified because of its rapid hydration. As could be expected and in spite of the samples' quartering, some unexpected results were obtained such as the presence of $\mathrm{Hg}_{2} \mathrm{Br}_{2}$.

For sample $\mathrm{A}$, it is clear that all the mercury compounds were concentrated in the condensates. On the other hand, copper selenide was converted to copper oxide and selenium which is reacted with mercury to form $(\mathrm{HgSe})$. The treatment's residue of sample B is almost free from arsenic and its sulfides were partially or fully oxidized to sulfates ${ }^{[3]}$. The decomposition of mimetite and the partial oxidation of sulfides, contained in the sample $\mathrm{C}$ are the main modifications produced by its treatment in air at $700{ }^{\circ} \mathrm{C}$. In the reference ${ }^{[7]}$ as reported the mass balance of possible reactions between the solid wastes and the gas stream. Good agreement was found among the calculated and experimental values of the samples' percentage weight losses in the temperature range of 20 to $800{ }^{\circ} \mathrm{C}$ as well as those of 20 to $400^{\circ} \mathrm{C}$ and 400 to $800^{\circ} \mathrm{C}$.

\subsection{Reducing treatment}

At the temperature lower than $600^{\circ} \mathrm{C}$, the weight loss is independent of the treatment's atmosphere (air or $\mathrm{H}_{2}$ ). However, the quantity of the weight loss, in presence of $\mathrm{H}_{2}$, is lower than that of air. Moreover, at temperatures higher than $600{ }^{\circ} \mathrm{C}$, reduction of sulfides and sulfates was performed. In order to characterize the reaction products, isothermal reduction of these samples was 
accomplished between 200 and $800{ }^{\circ} \mathrm{C}$ using an initial sample's weight of $10 \mathrm{~g}$.

The isothermal treatment shows that the pct weight losses of samples $\mathrm{A}, \mathrm{B}$ and $\mathrm{C}$ at $400^{\circ} \mathrm{C}$ were about 26, 53 and $20 \%$, respectively. As indicated by SEM and XRD analyses, the majority of $\mathrm{As}_{2} \mathrm{O}_{3}$ contained in samples $\mathrm{B}$ and $\mathrm{C}$ was volatilised between 20 and $400^{\circ} \mathrm{C}^{[8]}$. It should be stressed that $\mathrm{As}_{2} \mathrm{O}_{3}$ is irreducible by hydrogen below $400{ }^{\circ} \mathrm{C}$. The totality of mercury, contained in samples $\mathrm{A}$ and $\mathrm{B}$, was extracted at temperatures lower than $400^{\circ} \mathrm{C}$ and recovered in the condensates mainly as $\mathrm{HgSe}$. However, in this temperature range, volatilisation of selenium contained in sample $A$ was partial. On the other hand, the majority of sulfur and sulfur compounds was eliminated either through their volatilisation or after the decomposition of sulfates. In the temperature range of 400 to $800{ }^{\circ} \mathrm{C}$, the weight losses were about 31 , 8 and $24 \%$ for samples A, B and C, respectively. The major reactions taking place in this temperature range were the reduction of iron sulfide, iron oxide and lead sulfate ${ }^{[6]}$.

On the other hand, several sulfides were detected in the treatments' residues up to $800^{\circ} \mathrm{C}$. This is due to the presence of compounds such as $\mathrm{ZnS}$ that was irreducible. The calculated and experimental total pct weight losses at $800^{\circ} \mathrm{C}$, for samples A and B were in good agreement. According to SEM analysis, the most decontaminated residues were those obtained at $600{ }^{\circ} \mathrm{C}$.

After the systematic qualitative examination of the reaction products by SEM and XRD, chemical analyses were performed on residues that seemed to be the most decontaminated. The toxic elements were completely or partially eliminated from the residues of samples $\mathrm{A}$ and $\mathrm{B}$. On the other hand, the valuable metal contents of these samples were almost doubled. The treatment in air of sample $\mathrm{C}$ at $700{ }^{\circ} \mathrm{C}$ is inefficient. This is probably due to the presence of stable arsenic compounds.

The Global Decontamination Factor (GDF) of the treated samples is defined by the following equation:

$$
\mathrm{GDF}=\frac{\tau \times \sum T E_{\mathrm{i}}+\gamma \times \sum V M_{\mathrm{i}}}{\sum T E_{\mathrm{i}}+\sum V M_{\mathrm{i}}}
$$

Where:

$T E_{\mathrm{i}}=$ Initial content of toxic elements (As, $\mathrm{Hg}$, $\mathrm{Cd}$ and Se). $\tau=$ Total extraction rate of toxic elements; [(initial amount - final amount)/ initial amount] $* 100$.

$\mathrm{VM}_{\mathrm{i}}=$ Initial content of valuable metal $(\mathrm{Pb}, \mathrm{Zn}$ and $\mathrm{Cu}$ ).

$\gamma=$ Total Recovery rate of valuable metals; (final amount/ initial amount) $* 100$

GDF is equal to 100 , if the totality of valuable metals was recovered in the residue and toxic elements were completely eliminated and concentrated in the condensate. On the other hand, GDF will be equal to 0 if there isn't any extraction of toxic elements and any concentration of valuable metals. However, due to the heterogeneity of samples and the chemical analysis errors, values of $\gamma$ higher than $100 \%$ were observed. In this case, calculation of GDF was made using a $\gamma$ equal to 100 .

At $700^{\circ} \mathrm{C}$, figure 1 shows that the extraction rates of toxic elements were about 98,100 and 11 $\%$ for the samples A, B and C, respectively. GDF of treated residues, with air at $700^{\circ} \mathrm{C}$, was about 100 for samples A and B, respectively (Fig. 2). These results suggest that these samples were well decontaminated. However, the rates of extraction of toxic elements and that of recovery of valuable metals for sample $\mathrm{C}$ were about 11 and $86 \%$, respectively (Fig. 1). This is probably due to the presence of $\mathrm{Pb}_{5}\left(\mathrm{AsO}_{4}\right)_{3} \mathrm{Cl}$ in this sample. Finally, GDF was about 73 indicating that sample $\mathrm{C}$ is not fully decontaminated and consequently the oxidizing treatment of this sample was inefficient.

In reducing treatment at $600{ }^{\circ} \mathrm{C}$, figure 1 also shows that, the extraction rates of toxic elements for samples A, B and C were about 96,99 and 70 $\%$, respectively. The recovery rates of valuable

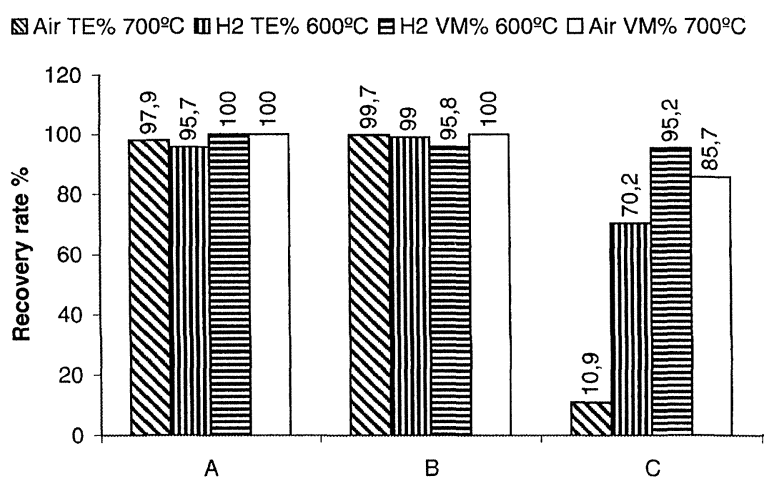

Figure 1. Recovery rates of toxic elements and valuable metals for three samples.

Figura 1. Tasas de recuperación para los elementos tóxicos y metales valiosos de las tres muestras.

Rev. Metal. Madrid 36 (2000) 


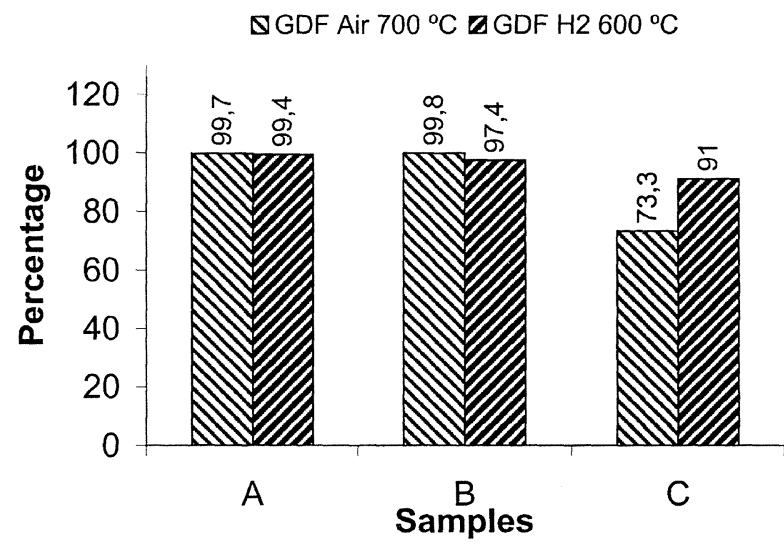

Figure 2. Calculated GDF for different treatments of three samples.

Figura 2. GDF calculado para los diferentes tratamientos de las tres muestras.

metals of these samples' residues were higher than $95 \%$. On the other hand, GDF of the treated residues, for samples $\mathrm{A}$ to $\mathrm{C}$ were 99,97 and 91, respectively (Fig. 2). These results show that samples A and B may be considered as well decontaminated and that treatment allows a fair decontamination of sample $C$. The reductive treatment of this sample was more efficient than its oxidizing treatment.

Table II gives an example of buying the wastes and the residues contained zinc and lead in France ${ }^{[9]}$. It indicates that the traces of some elements such as mercury, thalium and selenium contained in the treated wastes are very important in the input specification of non ferrous extraction processes. According to this table, it seems that the treated samples will be recycled with more or less important penalties.

Figure 3 describes the flow sheet of treatment of sample B. One step of drying at $105^{\circ} \mathrm{C}$ is necessary to remove about $51 \%$ of moisture contained in this dust sample. Approximately $49 \mathrm{~g}$ were treated in oxidizing atmosphere at $700{ }^{\circ} \mathrm{C}$ during $3 \mathrm{~h}$. The outlet gases (about $27 \mathrm{~g}$ ) contained the volatile compounds. The toxic solid wastes are removed after cooling and filtration of these gases. Generally, they contain arsenic, mercury compounds, and the mixture gases are treated before their rejection in atmosphere.

The residues obtained from the oxidizing treatment contain more than $52 \%$ of valuable

Table II. General conditions of buying the wastes and the residues contained zinc and lead ${ }^{[9]}$

Tabla II. Condiciones generales para la compra de residuos y desechos que contienen zinc y plomo ${ }^{[9]}$

\begin{tabular}{|c|c|c|c|c|c|c|}
\hline \multicolumn{4}{|c|}{ Zinc wastes } & \multicolumn{3}{|c|}{ Lead wastes } \\
\hline \multirow[t]{2}{*}{ Elements } & \multirow{2}{*}{$\begin{array}{c}\text { Admitted superior } \\
\text { limits (\%) }\end{array}$} & \multicolumn{2}{|c|}{ Penalty } & \multirow{2}{*}{$\begin{array}{c}\text { Admitted superior } \\
\text { limits (\%) }\end{array}$} & \multicolumn{2}{|c|}{ Penalty } \\
\hline & & $\mathrm{FF}$ & ht & & $\mathrm{FF}$ & ht \\
\hline As & 3 & 20 & $0.1 \%-0.1 \%$ & 3 & 20 & $0.1 \%-0.1 \%$ \\
\hline $\mathrm{Cl}$ & 6 & 10 & $0.1 \%-2 \%$ & 10 & 5 & $0.1 \%-0.5 \%$ \\
\hline $\mathrm{Na}+\mathrm{K}$ & 1 & 10 & $0.1 \%-0.3 \%$ & 1 & 10 & $0.1 \%-0.3 \%$ \\
\hline $\mathrm{Hg}$ & $100^{*}$ & 5 & $0.1 \mathrm{~g} / \mathrm{t}-20 \mathrm{~g} / \mathrm{t}$ & $100 *$ & 5 & $1 \mathrm{~g} / \mathrm{t}-20 \mathrm{~g} / \mathrm{t}$ \\
\hline $\mathrm{TI}$ & $200^{*}$ & 5 & $20 \mathrm{~g} / \mathrm{t}-50 \mathrm{~g} / \mathrm{t}$ & $200 *$ & 5 & $20 \mathrm{~g} / \mathrm{t}-50 \mathrm{~g} / \mathrm{t}$ \\
\hline $\mathrm{Se}$ & $100^{*}$ & 3 & $20 \mathrm{~g} / \mathrm{t}-20 \mathrm{~g} / \mathrm{t}$ & $100 *$ & 3 & $0.20 \mathrm{~g} / \mathrm{t}-20 \mathrm{~g} / \mathrm{t}$ \\
\hline $\mathrm{Cd}$ & 5 & 20 & $0.1 \%-0.2 \%$ & 1 & 20 & $0.1 \%-0.2 \%$ \\
\hline $\mathrm{Cu}$ & 5 & 10 & $0.1 \%-0.5 \%$ & 5 & 10 & $0.1 \%-0.5 \%$ \\
\hline Sn & 2 & 15 & $0.1 \%-0.1 \%$ & 2 & 15 & $0.1 \%-0.1 \%$ \\
\hline $\mathrm{F}$ & 1 & 20 & $0.1 \%-0.1 \%$ & 1 & 20 & $0.1 \%-0.1 \%$ \\
\hline $\mathrm{Bi}$ & & 20 & $0.01 \%-0.05 \%$ & & & \\
\hline $\mathrm{Zn}$ & & & & 5 & 30 & $1 \%-2 \%$ \\
\hline Organic materials & $\cdot$ & 20 & $0.1 \%-0.7 \%$ & 3 & 20 & $0.1 \%-0.7 \%$ \\
\hline
\end{tabular}

FF: French Franc, ht: higher than, * in ppm 


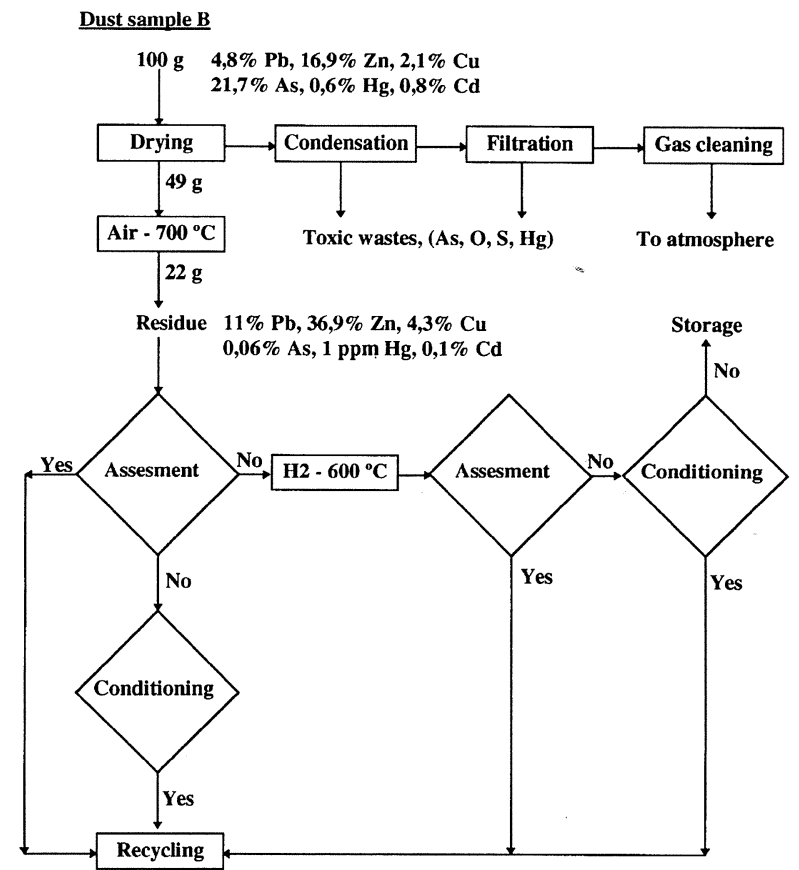

Figure 3. Flow sheet for treatment of dust sample B.

Figura 3. Esquema de flujo del tratamiento de la muestra $B$.

metals and about $0.2 \%$ of toxic elements. These residues are evaluated according to the specifications of the classical metallurgical processes feed. The conditioning is necessary before the recycling. Or use the treatment by hydrogen at $600{ }^{\circ} \mathrm{C}$ of the residue obtained from oxidizing treatment. The decontaminated wastes will evaluated ones again.

\section{CONCLUSIONS}

The treatments of three selected industrial wastes with air and hydrogen in the temperature range of 200 to $800{ }^{\circ} \mathrm{C}$ allow the following conclusions:

- The proposed treatment is function of the initial composition of the treated waste. It is difficult to design one flow sheet of treatment of all wastes.

- The oxidizing treatment is favourable for the samples $\mathrm{A}$ and $\mathrm{B}$, which allows to remove the quasi totality of toxic elements and to recover the valuable metals. However, this treatment is inefficient for sample $\mathrm{C}$ because the elimination of toxic elements was partial. On the other hand, due to the presence of mimetite $\left[\mathrm{Pb}_{5}\left(\mathrm{AsO}_{4}\right)_{3} \mathrm{Cl}\right]$ a part of valuable metals was chlorinated and concentrated in the condensates.

- The use of hydrogen at $600{ }^{\circ} \mathrm{C}$ permits the elimination of more than $96 \%$ of toxic elements and the recovery of up to $100 \%$ of valuable elements contained in the investigated industrial wastes. The obtained GDF values vary from 97 to $100 \%$. The concentration of valuable metals in the treatments' residues was almost doubled.

- According to the input specification of non ferrous extraction processes, it seems that the treated samples will be recycled with more or less important penalties.

In perspective, the study of the evolution of the physico-chemical properties as function of the time is necessary, and it is interesting to use the gas effluents generated from the industry which produces these wastes to treat them, or use other type of wastes to treat these wastes.

\section{Acknowledgements}

This work is realised thanks to the financial support of the "MRT" (Ministère de la Recherche et de la Technologie) and of the group COGEMA (Cómpagnie Générale des Matières Nucléaires), France. The authors also thank Messrs. Allain E. Kanari N. (LEM-GPE), for discussion and help on different subjects, S. Dominiak (University of Metz), J.M. Claude and A. Kohler (University of Nancy I) for the SEM and microprobe analyses, and F. Lhote (CNRS-CRPG) for XRD analysis.

\section{REFERENCES}

[1] Anonymous, Toxic Watch 1995, Inform Inc., 120 Wall street, New York, NY 10005.

[2] N. Menad and I. Gaballah, Oxidizing and Reducing Treatments of Industrial Hazardous wastes. Toxicological and Environmental Chemistry, 1999, 1-18.

[3] N. Menad, E. Allain, I. Gaballah, P. Pardo and J.C. Ruiz Rev. Metal. Madrid, 32 (1996) 160-166.

[4] I. Gaballah, E. Allain and M. Djona, Proc. of the technical sessions, Light Metals Committee at the 123 rd TMS annual meeting San Francisco, (USA) Feb. 27 March 3, 1994, pp. 1153-61.

[5] N. Kanari, E. Allain, I. Gaballah, A. Hernández and F. García-Carcedo Rev. Metal. Madrid, 35 (1999) 3-10.

[6] N. MENAD, Ph.D. Thesis, Institut National Polytechnique de Lorraine, Vandœuvre, France, 1995.

[7] I. Gaballah, N. Menad, F. García-Carcedo, D. Siguín, and S. Ferreira Rev. Metal. Madrid, 31 (1995) 143-149.

[8] I. Gaballah, N. Menad, E. Allain, M. Djona, G. Lyaudet and P. MICHEL, Treatment and minimization of heavy metal-containing wastes Int. Symp., TMS, Las Vegas, (USA), 1995, pp. 181-199.

[9] Private communication, I. GABAllaH with ChaBRY, Metal Europe, Pas de Calais, France, 1994. 